\title{
The Functional Analysis and Realistic Observation of Hu Shi's Experimentalism
}

\author{
Liuqi Wang \\ School of International Education \\ Nanyang Institute of Technology \\ Nanyang, China 473004
}

\begin{abstract}
This article conducts the functional analysis and realistic observation of Hu Shi's experimentalism. First of all, it analyzes Hu Shi's experimentalism, then discusses the unique functions of experimentalism, finally analyzes the practical guiding significance of Hu Shi's experimentalism from multiple perspectives.
\end{abstract}

Keywords-Hu Shi; experimentalism; functional analysis; realistic observation

\section{INTRODUCTION}

\section{A. Evolution of Hu Shi's Experimentalism}

Dewey's theory played a decisive role in the evolution of $\mathrm{Hu}$ Shih's experimentalism. It activated $\mathrm{Hu}$ Shi's already existing thought factor [1]. Another major reason for $\mathrm{Hu}$ Shi to attach great importance to experimentalism is that before he came into contact with experimentalism, he had shown great interest in the study methods used by Qing scholars in China, and had compared and analyzed related textual research articles[2]. Therefore, Hu Shi was able to approach and accept Dewey's experimentalism by virtue of his qualities in the field of textual research, and thus found a new way which combined experimentalism and traditional Chinese studies. In the framework of experimentalism, the operating methods of "hypothesis" and "certification" are intrinsically the same with the traditional Chinese textual research methods. They belong to the same category. This prompted Hu Shi's acceptance of Dewey's experimentalism. At the same time $\mathrm{Hu}$ Shi placed suspicions, assumptions, and confirmations at an important position.

\section{B. Experimentalism and Positivism}

Some people call "experimentalism" as "instrumentalism", but in $\mathrm{Hu}$ Shi's view, "experimentalism" seems more appropriate, although the latter is more "technical". Experimentalists believe that all the problems of people and society can be explored through scientific methods and attitudes. Attaching importance to experience, paying attention to the process, and actively practicing are the main components. The positivism was put forward by Comte in the 19th century. It is also often used in the study of history, philosophy and sociology[3]. Positivism attempts to demonstrate philosophy as an empirical science. Positivist historians believe that history can be treated as an empirical science. This view will become the realistic basis for history's becoming occupational and scientific. It can thus be seen that both experimentalism and positivism were initially located in the field of philosophy and both emphasized the necessity to use scientific methods to study. Of course, the difference between the two is also very obvious, experimentalism attaches great importance to the experimental process, while positivism pays attention to the results.

\section{THE UNIQUE FUNCTIONS OF HU SHI'S EXPERIMENTALISM}

\section{A. Practical and Innovative Scientific Attitude}

To prove whether a hypothesis is scientific and reasonable or whether it can solve the problem, it is necessary to "give evidence". And we should continuously innovate when solving specific problems [4]. The core of scientific experimentalism is "giving evidence", which fully reflects the scientific attitude of "seeking truth from facts". When discovering and innovating truths through experimentalist methods, we have experienced the process from suspicion to seeking truth from facts to obtaining evidence. This is intrinsically coincident with the ideological line that our party upholds and the Marxism we advocate.

\section{B. Breakthroughs in Time and Space Limitations}

The experimentalism approach is based on contemporary scientific outlook on life. Scientific outlook on life and cosmology is to study or evaluate the value and significance of life from three different dimensions: time and space, material universe, and biosphere. Exploring society through experimentalist scientific methods not only needs to go through the space-time of history, but also needs to cross the space-time of reality and invent the space-time of the future, studying the past, present, and future of life from different dimensions [ 5].

\section{Acquiring New Experience by Trying}

$\mathrm{Hu}$ Shi pointed out that "success comes from trying since ancient times". The experimentalism methodology must embody the experimental spirit of bravely trying, not being afraid of failure, and perseverance. In fact, Hu Shi's various contributions should be attributed to experimentalism [6-8]. If we don't have the unremitting experimental spirit or don't 
continuously practice, not only we can't turn the "bold hypothesis" into a spiritual achievement, but also we can't continuously make progresses and innovations in academic research.

\section{Gathering Focused Issues}

After studying and predicting time and space of history, present and future, we can find many life issues. Some issues are easy to deal with, while others are focused and central issues that may affect all other issues. These focused issues can be identified and selected by using scientific value standards and scientific thinking methods[9]. The experimentalism based on the values of modern science has the ability to discover and gather the core issues from many complex problems. That is exactly the ability to find major contradictions among numerous contradictions.

\section{E. Optimizing Individual Wisdom}

When solving life and social problems, we must use our own experience, knowledge, and ideas, give full play to imagination, and carry out bold assumptions purposefully. Generally, such a hypothetical must rely not only on rich creative wisdom and reliable theory, but also on the scientific spirit to constantly enrich it[10]. Hu Shi emphasized in particular that the premise of the "bold hypothesis" was "many living knowledge" and "these living knowledge originate mainly from human conscious activities". Only the "experience acquired from activities" is "authentic and reliable knowledge". The "conscious activity" mentioned above refers to the practical activities carried out under the scientific guidance.

\section{The REALISTIC GUIDING SignifiCANCE OF HU SHI's EXPERIMENTALISM}

\section{A. The Scientific View of Life Is an Eternal View of Life}

From a philosophical point of view, people exist in history and in the process of social development [11]. Therefore, the significance of "living" is related to history and society. It is necessary to seek the meaning of "being" from history and society. In this sense, history and society are immortal, and any individual is not isolated. It has direct and indirect links with countless other individuals. They have influenced and affected each other in the process of fusing with the world. This also determines that there is a causal relationship between the existence of any individual and the past, present, and future of the world. Therefore, Hu Shi's "social immortality" can make us realize that the scientific view of life is the eternal view of life, and any individual should be aware of his own behavior (moral, social, and historical) and be responsible for it.

\section{B. The Individuals Should Fully Play Their Historical Subject Functions and Undertake Their Social Responsibilities}

Since the society's "self" is made up of countless individuals' "selves", the quality of society inevitably depends on the individual's quality. Therefore, Hu Shi believes that in any autonomous society, except that individuals' personal freedom of choice should be respected, individuals should be responsible for their own behavior. [12]. Otherwise, the "independent personality of the individual" required by the "high-quality society" will not be shaped, and the hope of the state for improvement and progress will eventually shatter. Further, Hu Shi pointed out that individuals should follow their own conscience in the society filled with materialistic desires and worldliness, and should make correct judgments based on their conscience, rather than accommodate the sound of society. This assertion, which was proposed many years ago, actually can be applied in any society that wishes to achieve progress. When the society develops into a dilemma, the individual's primary task is to "save himself". Because saving himself is equivalent to "saving one more person"; winning the freedom of himself is equivalent to "getting freedom for the country"; getting the personality of the individual is equivalent to "getting the personality for the state". At the same time, Hu Shi believes that the individual is the ultimate entity of social existence and development. The survival of individual personality is the basis for the country and society to own free and independent spirit and it is the power of social progress. This has extremely important practical significance for the progress of society.

\section{Updating the View of Life Is the Need of the Times}

In $\mathrm{Hu}$ Shi's view, there are two basic ideals in the traditional view of life[13]. One is the "spirit perpetuity theory" in religion, and the other is the "cultivating characters, making careers, writing good articles" "three immortality theory" in the traditional culture of China. "Cultivating characters" is related to personality; "making careers" is related to career; and "writing good articles" is related to language and writing, such as poets $\mathrm{Li} \mathrm{Bai}$ and $\mathrm{Du} \mathrm{Fu}$, writers Liu Zongyuan, Fan Zhongyan, thinkers Huang Zongxi, Gu Yanwu, and Wang Fuzhi. However, Hu Shi believes that the "three immortality theory" is very narrow and only related to a few people in the society. It is the so-called "oligarchic immortality theory". It has nothing to do with the vast majority of people. Therefore, it is imperative to renew the view of life, which is also the need of the times.

\section{CONCLUSION}

The "bold hypothesis and careful verification" is only an overview of Hu Shi's experimentalist approach. The scientific method is "suspecting $\rightarrow$ hypothesis $\rightarrow$ verification". Hu Shi used this method in many fields such as philosophy, literature, and history, and had many achievements. Even today, we can still find out information that has practical guidance significance from the achievements. Of course, no method is omnipotent and everyone has its scope of application. So does $\mathrm{Hu}$ Shi's experimentalism. However, we should realize that Hu's application of experimentalism method has greatly promoted the development of the academic research in China, promoted the transformation of people's ideas in the development of society and the integration of Chinese and Western cultures. Although in terms of specific academic achievements, Hu Shi seems unable to compare with Wang Guowei and Chen Yinke. However, his achievement in world outlook and methodology has surpassed that of others by more 
than half a century. It is an unparalleled achievement for scholars who study a specific academic field.

\section{REFERENCES}

[1] Zhu Wenhua. Critical Biography of Hu Shi [M] Chongqing: Chongqing Publishing House, 1998. 朱文华. 胡适评传[M]重庆: 重庆出版社, 1998

[2] Tang Degang. Hu Shi's historical position and historical role [A] Zitong. Comments on $\mathrm{Hu}$ Shi over eighty years [M] Beijing: The Chinese Overseas Publishing House, 2003. 唐德刚.胡适的历史地位与历史作 用 $[\mathrm{A}]$ 子通.胡适评说八十年 $[\mathrm{M}]$ 北京: 中国华侨出版社, 2003

[3] Geng Yunzhi. The modern significance of $\mathrm{Hu}$ Shi's thought [J] Academic exploration. 2006(2):pp.12-14. 耿云志.胡适思想的现代意 义[J]学术探索. 2006(2): 12-14

[4] Hu Shi, Scientific View of Life [A] Hu Shi's Complete Works: Volume 7 [M] Hefei : Anhui Education Press, 2003. 胡适, 科学的人生观 [A] 胡适全集: 第 7 卷 $[\mathrm{M}]$ 台肥: 安徽教育出版社, 2003

[5] Hu Shi's Experimentalism [J] New Youth, 1919 (Volume6 number4). 胡适实验主义[J]新青年, 1919 (6 卷 4 号)

[6] Zhu Defa. Indispensable methodology for constructing Chinese new culture - Interpretation of Hu Shi's experimentalism[J]. The Journal of Theory, 2007(4). 朱德发.建构中国新文化不可或缺的方法论一一 解读胡适的实验主义观[J]理论学刊, 2007(4)

[7] Wang Qiming. From Chinese and Western secretly integration to Chinese and Western combination: Analyzing the Origin and Formation of Hu Shi's Experimentalism [J] Cultural Studies, 2009 (11). 王启明.从 中西暗合到中西舍璧——论胡适实验主义的起源及形成 [J]文化研 究, 2009(11)

[8] Hu Qin'e, Xia Shujuan. The application of Hu Shi's experimentalist scholarship methods: Taking Hu Shi's research on " The Story of the Stone " as an example [J] Journal of Anhui University (Philosophy and Social Studies), 2007 (3). 胡琴娥, 夏淑娟.胡适实验主义治学方法的 运用一一以胡适对《红楼梦》的考证为例 $[J]$ 安徽大学学报（哲学 社会利学版），2007（3）

[9] Yang Zhihua, Yu Yangyou. Analysis of Hu Shi's characteristic experimentalism and its application in historiography research [J] Journal of Huangshan University, 2011(8). 杨志华，余洋有.胡适特色 的实验主义及其与史学研究探析[J]黄山学院学报, 2011（8）

[10] Liu Zuoqin. Analysis of Reasons for Hu Shi's Approach to Dewey's Experimentalism [J]. The Science Education Article Collects, 2008 (7). 刘作芹.浅析胡适走近杜威实验主义的原因 [J].利教文汇, 2008(7)

[11] Shao Yisheng, New Exploration for $\mathrm{Hu}$ Shi and Experimentalist History[J] Heilongiiang Local History, 2011(7). 邵一升, 胡适与实验 主义史学新探[J]黑龙江史志，2011（7）

[12] Liu Fangtong. Dewey's philosophy and its influence in China [J]. Tianjin Social Science, 2010 (2). 刘放桐.杜威哲学及其在中国的影响 [J].天津社会科学, 2010(2)

[13] Zhang Guangzhi. History of Western History[M] Shanghai: Fudan University Press, 2008. 张广智.西方史学史 $[\mathrm{M}]$ 上海: 复旦大学出版 社 2008 